\title{
ACUTE TOXICITY OF AMMONIA ON JUVENILE COBIA (RACHYCENTRON CANADUM, LINNAEUS, 1766) ACCORDING TO THE SALINITY
}

\author{
Barbieri, E. ${ }^{1}$; Doi, S. A. ${ }^{2}$ \\ 1- Instituto de Pesca - APTA - SAA/SP. Caixa Postal 61. Av. Prof. Besnard, s/n, 11990-000. Cananéia, SP, Brazil. E- \\ mail: edisonbarbieri@yahoo.com.br. 2 - Programa de Pós-Graduação do Instituto de Pesca-SP. E-mail: \\ soniasdoi@gmail.com.
}

\section{RESUME}

Juvenile cobia (Rachycentron canadum) were exposed to different concentrations of ammonia$\mathrm{N}$ (un-ionized plus ionized ammonia as nitrogen), using the static renewal method at different salinity levels of $5 \%, 20 \%$ and $35 \%$ at pH 8.1 and $25^{\circ} \mathrm{C}$. The $24,48,72,96 \mathrm{~h}$ LC50 values of ammonia-N for $R$. canadum juveniles were $60.28,48.57,37.42,22.73 \mathrm{mg} \mathrm{I}^{-1}$ at $35 \%$; 51.25 , $43.63,28.17,19.05 \mathrm{mg} \mathrm{I}^{-1}$ at $20 \%$; $39.48,25.31,19.50,8.13 \mathrm{mg} \mathrm{I}^{-1}$ at $5 \%$, respectively. The 24 , $48,72,96 \mathrm{~h}$ LC50 values of $\mathrm{NH}_{3}-\mathrm{N}$ (un-ionized ammonia as nitrogen) were 1.81, 1.46, 1.12 and $0.68 \mathrm{mg} \mathrm{I}^{-1}$ at $35 \%$; $1.75,1.49,0.96$ and $0.65 \mathrm{mg} \mathrm{I}^{-1}$ at $20 \%$; and $1.52,0.97,0.71$ and $0.31 \mathrm{mg}$ $\mathrm{I}^{-1}$ at $5 \%$, respectively. As the salinity decreased from $35 \%$ to $5 \%$, susceptibility of ammonia- $\mathrm{N}$ increased by $34.5 \%, 47.88 \%, 50.56 \%$ and $64.23 \%$ after $24,48,72$ and $96 \mathrm{~h}$ exposure, respectively. Furthermore, we found that exposure of fish to ammonia- $\mathrm{N}$ caused an increase in oxygen consumption of $129.1 \%, 157.5 \%$ and $192 \%$, with respect to the control.

Keyword: metabolism, respiration

\section{INTRODUCTION}

Fish farming has been intensified due to limitation and availability of ponds. In an intensive culture system, ammonia is the commonest toxicant resulting from the excretion of cultured animals and mineralization of organic detritus such as unconsumed food and feces (LIN et al., 2003). Accumulation of ammonia in pond water may deteriorate the quality of the water, reduce growth, increase oxygen consumption and ammonia- $\mathrm{N}$ excretion, alter concentrations of hemolymph protein and free amino acid levels, and even cause high mortality (WICKINS et al., 1976). The purpose of the present study is to estimate ammonia toxicity, oxygen consumption and ammonia excretion at salinity levels of $5 \%, 20 \%$ and $35 \%$, in Rachycentron canadum juveniles.

\section{MATERIALS AND METHODS}

One hundred and fifty Cobia, weighing an average of $1.57( \pm 0.5) \mathrm{g}$ and measuring an average of $1.62( \pm 0.36) \mathrm{cm}$ in length, were used for the routine metabolism measurements using sealed respirometers. The respirometer was made in our laboratory, with a tube of acrylic and PVC covers. Ten fish were subjected individually to oxygen consumption measurements in one of the concentrations of ammonium chloride $(0.0,5,10,20$, and $40 \mathrm{mg} / \mathrm{l})$. The $\mathrm{pH}$ and oxygen concentration of the test solution at the different concentrations of ammonium chloride were measured: the range of $\mathrm{pH}$ values was $8.00-8.07$. The range of oxygen values was 6.35$6.55 \mathrm{ml}$ oxygen/l. The dissolved oxygen was determined through the Winkler Method (WINKLER, 1888).

\section{RESULTS}

For the fish acclimated at $25^{\circ} \mathrm{C}$, the specific oxygen consumption increased with respect to the ammonia- $\mathrm{N}$ concentration for the three salinities. The specific oxygen consumption in any ammonia- $\mathrm{N}$ concentration increased with a decrease in salinity. The specific oxygen consumption of fish from the acclimated control group was measured at $25^{\circ} \mathrm{C}$ (Figure 1), for $35 \%$, $20 \%$ and $5 \%$ salinity. The values were, $2.4,2.33$ and $2.6 \mathrm{mlO} / \mathrm{g} / \mathrm{min}$, respectively. For the fish exposed to the concentration of $40 \mathrm{mg} / \mathrm{l}$ of ammonia- $\mathrm{N}$, the consumption was $5.5,6.0$ and $7.6 \mathrm{ml} \mathrm{O} / \mathrm{kg} / \mathrm{min}$ for the tested salinities. These values represent an increase in the metabolic level of $129.1 \%, 157,5 \%$ and $192 \%$ with respect to the control. Using the Tukey $(p<0.05)$ statistical test, it was verified that the averages of the oxygen specific consumption for 
ammonia-N at 20 and $40 \mathrm{mg} \cdot \mathrm{L}^{-1}$ concentration in all salinities are different with respect to the control. The same test showed that there is a difference between the specific consumption averages for the salinities $5 \%$ and $35 \%$, and for the ammonia- $N$ concentrations of 10,20 and $40 \mathrm{mg} \cdot \mathrm{L}^{-1}$.

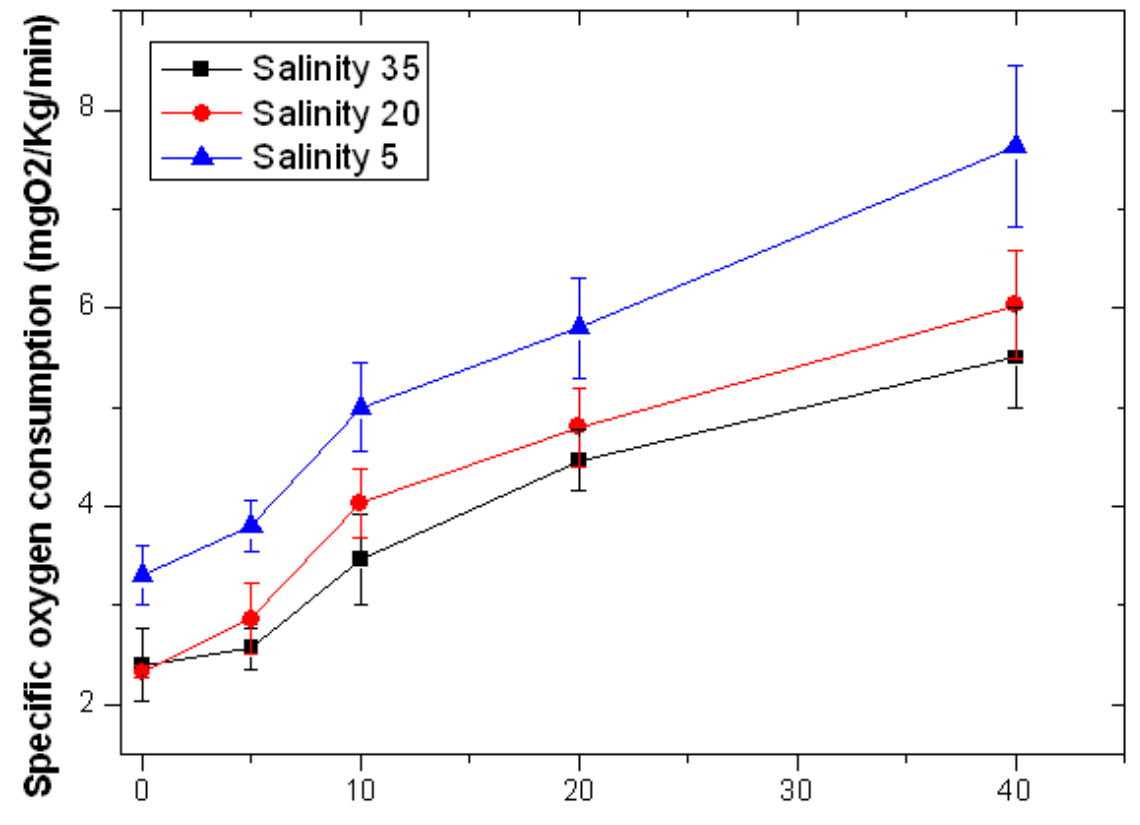

Ammonia-N concentration ( $\mathrm{mg} / \mathrm{L}$ )

Fig. 1 Variation in specific oxygen consumption of Cobia at different Ammonia-N concentrations. The bars are the respective standard deviations $(n=5)$.

\section{DISCUSSION}

Studies on the effect of ammonia- $\mathrm{N}$ on the respiration of fish demonstrated that the increase in oxygen consumption rates was related to concentration, exposure time, and larval stage (SMART, 1978; BARBIERI, 2009). LAMARIÉ et al. (2004) indicated that ammonia-N as low as $0.370 \mathrm{mg} / \mathrm{L}$ would cause an increase in oxygen consumption and ammonia-N excretion of seabass juveniles $(0.079 \pm 0.004 \mathrm{~g})$ in 20 hours. ARANDA (2000), in a review of the responses of aquatic organisms in low ambient dissolved oxygen, mentioned that many fish possess an excellent regulatory ability in their oxygen consumption patterns and thus were called oxygen regulators. The present experiments also demonstrated that oxygen consumed by Cobia showed no linear relationship to ambient oxygen levels, regardless of whether the fish were exposed to ammonia-N. Despite their regulatory capability, the oxygen consumption rate was indeed increased after Cobia was exposed to high concentrations of ammonia-N. Similar results were also observed in different fish species (LAMARIÉ et al., 2004).

\section{ACKNOWLEDGEMENTS}

Would like to thank the FAPESP (processo 2007/50147-7) and CNPq (Processo 308700-4 - Bolsa de produtividade), for their support during the undertaking of this study.

\section{REFERENCES}

ARANDA, L.V. 2000. Princípios químicos da qualidade da água em aqüicultura. Florianópolis/SC, Ed. da UFSC. 166p.

BARBIERI, E. 2009 Effects of zinc and cadmium on oxygen consumption and ammonium excretion in pink shrimp (Farfantepenaeus paulensis, Pérez-Farfante, 1967, Crustacea). Ecotoxicology. 18(3): 312-318 
LAMARIÉ, G.; DOSDAT, A.; COVĖS, D.; DUTTO, G.; GASSET, E.; RUYET, P. 2004. Effect of chronic ammonia exposure on growth of European seabass (Dicentrarchus labrax) juveniles. Aquaculture. 229: 479-491.

LIN, C. Y.; CHEN., J. C. 2003. Acute toxicity of nitrite on Litopenaeus vannamei (Boone) juveniles at different salinity levels. Aquaculture. 224 (1-4):193-201.

WICKINS, J. F. 1976. The tolerance of warm-water prawn to recirculated water. Aquaculture. 9: $19-37$. 